 \\ 初期たわみを有する補強長方形板の非線形自由振動 \\ （第 3 報）実＼cjkstart験*1

\section{Free Nonlinear Vibrations of Stiffened Rectangular Plates with an Initial Curvature} \\ (Part 3) Experiment \\ 角誠之助*2 ・有 冨 正 男*3 \\ Seinosuke SUMI, Masao ARITOMI \\ 桐 岡 健 ${ }^{* 3}$ \\ and Ken KIRIOKA
}

Key Words : Structural Analysis, Free Nonlinear Vibration, Stiffened Rectangular Plate, Initial Curvature, Experiment

\begin{abstract}
This paper presents an experimental investiga. tion of the linear (small amplitude) and nonlinear (large amplitude) fundamental vibrations of orthotropic stiffened square plates with a small initial curvature. The stiffened plates are made of toughpitch copper plates by photo-etching. The plates are excited by a speaker and the modes of linear vibra. tion are measured by laser holography. The effects of the initial curvatures on the vibration modes and the variations of eigen-frequencies with the amplitude are clarified. The experimental results are found to verify the previously theoretical investigations.
\end{abstract}

\section{1. 緒言}

前報1.2)では， smeared out 法により直交補強板を 等価な直交異方性板に置き換え，初期たわみを有する 補強長方形板の非線形自由曲げ振動の基礎式を誘道す るとともに，Galerkin 法と逐次近似法を用いて周辺 単純支持板と周辺固定板の基本振動に対する近似解を 求め, 初期たわみや振幅さらには補強材と板の剛性比 が補強板の振動特性に及ほす影響を明らかにした。

一方，補強板の曲げ振動に関する実験的研究は既に いくつか報告されている．例えば, Hoppmann ら $5^{3,4)}$ は全周辺が単純支持された一方向補強板の曲げ振動実

\footnotetext{
${ }^{* 1}$ 昭和 61 年 7 月 18 日，第 28 回構造強度に関する諈演会お よび昭和 62 年 7 月 17 日，第 29 回槽造強度に関する講演 会にて講演. 平成 2 年 6 月 4 日原稿受理

*2 九州大学工学部航空工学科

*3 鹿児島大学工学部機械工学科
}

験を行い，補強板を等価な直交異方性板に置き換えて 求めた固有振動数の近似式の妥当性を検討している. また, Olson と Hazell'5) は 1 本および 2 本のりプで補 強された正方形板の振動モードをレーザホログラフィ て測定し, 同時にその時の固有振動数を計測して有限 要素法による結果と比較している，さらに，斎藤と山 口゙) は粘弾性ばりが板の振動減衰特性に及伊す影響 を，実験と伝達マトリックス法による解析により明ら かにしている。しかしながら，初期たわみを有する補 強板の非線形振動に関する実験的研究はほとんど見当 たらない.

そこで本報は理論解析 ${ }^{1,2)}$ と同時に実験を行い, 両 者を比較検討したものである.まずタフピッチ銅板を フォトエッチングにより腐食させて補強平板を製作 し，それを理論解析で用いた初期たかみ曲面をもつ金 型に挟んで電気炉内で加熱し，浅い曲面を有する補強 板試験片を製作した．次にスピーカによる音響加振法 で、線形および非線形の振動実験を行い，理論解析の 妥当性を検討した。また線形振動実験で、レーザホ ログラフィの時間平均法により振動モードを測定し，

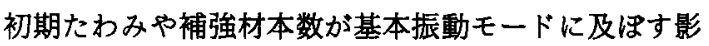
響を明らかにした。

\section{2. 試験片および試験片取付伜}

2.1 試験片 試験片を製作したタフピッチ銅板の 材料定数を第 1 表に示す．また表中に薄板（補強材な しの薄板を，本報では単に薄板と呼ぶ）として示した 試験片は，補強板の実験に先立って，まず試験片取付 枠の全周辺単純支持，あるいは全周辺固定の境界条件 が実現できているかの検証実験に用いた．補強板試験 
片は第 1 図のように厚さ $H=1.00 \mathrm{~mm}$ の銅板をフォ トエッチングにより腐食させ，非補強部の厚さ $h$ (こ の板厚 $h$ の等厚長方形板を前報 ${ }^{1,2)}$ と同じくここでも 非補強板と呼占）が $0.35 \mathrm{~mm}$ の二方向補強板と 0.37 $\mathrm{mm}$ の一方向補強板を製作した。これら第 1 図の補強 板に smeared out 法を適用すれば，補強材と非補強 板との伸び剛性比 $\alpha_{\mathrm{s}}, \alpha_{\mathrm{r}}, \alpha_{\mathrm{sr}}$ ，曲げ剛性比 $\beta_{\mathrm{s}}, \beta_{\mathrm{r}}$ ，标じ り䣓性比 $\beta_{\mathrm{sr}}$ およひ質量比 $\bar{\rho}$ は第 1 報の(6)式, (7)式より

$$
\left.\begin{array}{l}
\alpha_{\mathrm{s}}=2\left(1-\nu^{2}\right) \frac{w_{\mathrm{s}} h_{\mathrm{s}}}{d_{\mathrm{s}} h}, \alpha_{\mathrm{r}}=2\left(1-\nu^{2}\right) \frac{w_{\mathrm{r}} h_{\mathrm{r}}}{d_{\mathrm{r}} h} \\
a_{\mathrm{sr}}=\frac{w_{\mathrm{s}} h_{\mathrm{s}}}{d_{\mathrm{s}} h}+\frac{w_{\mathrm{r}} h_{\mathrm{r}}}{d_{\mathrm{r}} h}, \beta_{\mathrm{s}}=\alpha_{\mathrm{s}}\left[3+6 \frac{h_{\mathrm{s}}}{h}+4\left(\frac{h_{\mathrm{s}}}{h}\right)^{2}\right] \\
\beta_{\mathrm{r}}=\alpha_{\mathrm{r}}\left[3+6 \frac{h_{\mathrm{r}}}{h}+4\left(\frac{h_{\mathrm{r}}}{h}\right)^{2}\right], \beta_{\mathrm{sr}}=\frac{3}{h^{3}}\left(\frac{J_{\mathrm{s}}}{d_{\mathrm{s}}}+\frac{J_{\mathrm{r}}}{d_{\mathrm{r}}}\right) \\
\bar{\rho}=2\left(\frac{w_{\mathrm{s}} h_{\mathrm{s}}}{d_{\mathrm{s}} h}+\frac{w_{\mathrm{r}} h_{\mathrm{r}}}{d_{\mathrm{r}} h}\right)-\frac{m_{\mathrm{sr}}}{\rho h a b}
\end{array}\right\}
$$

で与えられる。だし， $\beta_{\mathrm{sr}}$ の中の $J_{\mathrm{s}}, J_{\mathrm{r}}$ は板両面の 補強材 1 組のねじり定数で，ここでは近似的に

$$
\begin{aligned}
J_{\mathrm{s}} \fallingdotseq & \frac{\left(h+2 h_{\mathrm{s}}\right)^{3} w_{\mathrm{s}}}{3}\left(1-\frac{192}{\pi^{5}} \cdot \frac{h+2 h_{\mathrm{s}}}{w_{\mathrm{s}}}\right) \\
& -\frac{h^{3} w_{\mathrm{s}}}{3}\left(1-\frac{192}{\pi^{5}} \cdot \frac{h}{w_{\mathrm{s}}}\right)
\end{aligned}
$$

\begin{tabular}{|c|c|c|c|c|}
\hline \multicolumn{2}{|c|}{ 試臨片の種類 } & $\begin{array}{c}\text { 縦弾性係数 } \\
E \mathrm{GPa} \\
E \mathrm{Ga}\end{array}$ & $\begin{array}{c}\text { ポアソン比 } \\
\nu\end{array}$ & $\begin{array}{l}\text { 密度 } \\
\rho \mathrm{g} / \mathrm{cm}^{3}\end{array}$ \\
\hline \multirow{2}{*}{ 薄 板 } & $h=0.68 \mathrm{~mm}$ & 126 & \multirow{4}{*}{0.33} & \multirow{4}{*}{8.96} \\
\hline & $h=1.00 \mathrm{~mm}$ & 115 & & \\
\hline \multicolumn{2}{|c|}{ 二方向補強板 } & 116 & & \\
\hline \multicolumn{2}{|c|}{ 一方向補強板 } & 115 & & \\
\hline
\end{tabular}

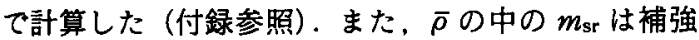
材が交差する部分の補強材質量である，補強材本数 $n$ は第 2 表に示すように $5,10 ， 15 ， 20 ， 30$ 本と異なる が，（1）式で計算した伸び用性比 $\alpha_{\mathrm{s}}, \alpha_{\mathrm{r}}$ と曲げ用性比

\section{第 1 表 試験片の材料定数}

$\beta_{\mathrm{s}}, \beta_{\mathrm{r}}$ がそれぞれ一定值となるように補強材寸法を設 定した．その設計寸法を第 2 表に示すが，所定の厚さ $h$ を精度よくエッチングすることは非常に難しく，製 作した試験片は表示の寸法に対していくぶんばらつい たものとなった。なお，試験片の外形寸法はすべて $a$ $\times b=150 \mathrm{~mm} \times 150 \mathrm{~mm}$ の正方形である.

ところで，タフピッチ銅板は冷間圧延加工により製 作されているため残留ひずみが生じている，そこで， 試験片を $250^{\circ} \mathrm{C}$ 電気炉内で 80 分間加熱したのち約 6〜10 時間炉内冷却して焼鈍を行い，残留ひずみを取 り除いた。また，試験片の初期たわみは金型や木型に よって圧造する方法 ${ }^{7,8)}$ もあるが、 spring back のため あまり正確な形状が得られない。そこで本報では，焼 鈍後の試験片を理論解析1,2) で用いた初期たわみ形状 $\xi$ 、つまり

(a) 周辺単純支持板

$$
\xi=B \sin \frac{\pi x}{a} \sin \frac{\pi y}{b}
$$

(b) 周辺固定板

$$
\left.\xi=\frac{B}{4}\left(1-\cos \frac{2 \pi x}{a}\right)\left(1-\cos \frac{2 \pi y}{b}\right)\right)
$$

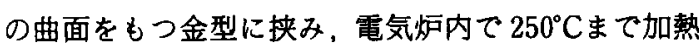
して一定時間保持したのち徐冷することで初期たわみ を与えた．このとき，加熱時間を調整することで最大 初期たわみ量 $B$ の大きさを種々変えることができた．

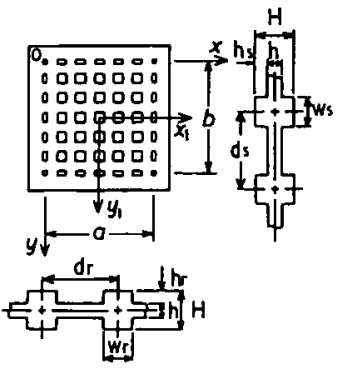

(a) 二方向補強板

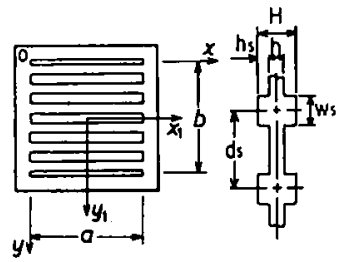

(b) 一方向補強板
第1図試験片外形

第 2 表 補強板試験片の寸法

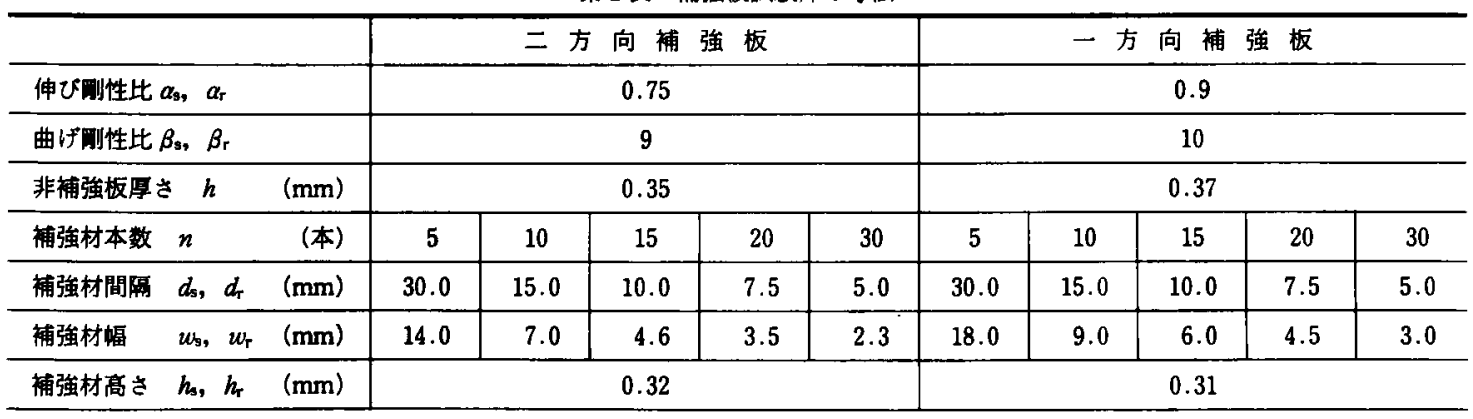


例として $x$ 軸方向に 10 本の補強材をもつ一方向補強 板の中心軸上の初期たわみ形状を，三次元変位測定機 で計測した結果を第 2 図に示す：横軸の $x_{1}, y_{1}$ 座標は 第 1 図に示すように $x, y$ 座標を板中心に原点をとっ て平行移動させたものである.（a）図は今回製作し た試験片で最も大きな初期たかみをもつ周辺単純支持 板の測定結果であるが，補強材の配置方向に垂直な $y_{1}$ 軸方向では曲がりやすい非補強部の影響を受けて 全体に膨らみ，最大初期たわみ点が板中心点からいく ぶんずれた形状となっている．（b)図の周辺固定板 の場合には余弦曲線によく一致した形状が得られてお り，周辺単純支持板，周辺固定板のいずれの試験片も すべて( 3 )式の曲面に近い初期たわみ形状が得られて いるのがわかる.なお，初期たわみのない場合の試験 片は，平らな金型に挟んで初期たわみを与えた場合と 同じ熱処理を行い，その初期不整を取り除いた。

2.2 試験片取付枠 周辺が単純支持された曲面板

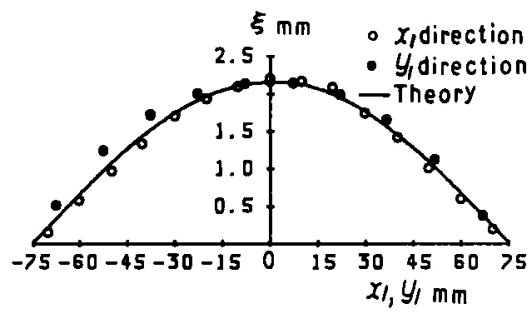

(a) 全周辺単純支持板 $(B=2.16 \mathrm{~mm})$

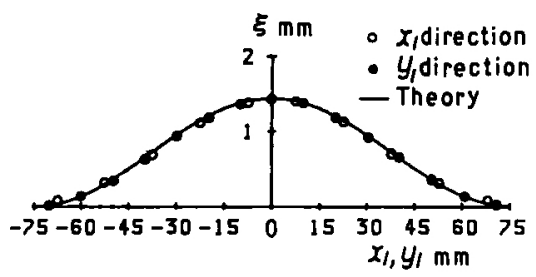

（b）全周辺固定板 $(B=1.44 \mathrm{~mm})$

第 2 図試駼片の初期たわみ形状 (一方向補強板， $n=10$ 本)

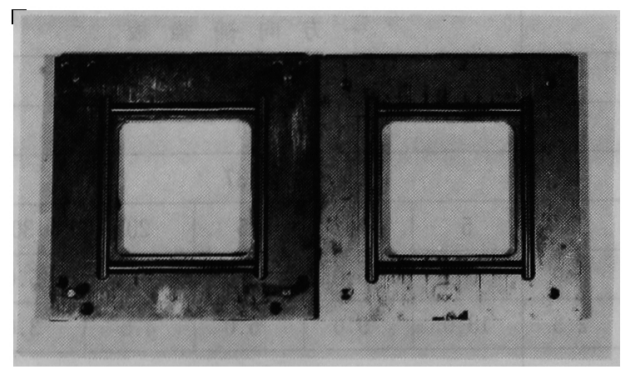

第 3 図武臨片取付枠（全周辺単純支持）
や補強板の曲げ振動実験に関する報告は，境界条件を 満足させるのが困難なためあまりなされていない，例 えば，補強長方形板の曲げ振動実験て，Hoppmann ら ${ }^{3,4)}$ は試験片周辺に漊を作りそれを平らな細いりム で囲んで，また斎藤と山口゙) は全周辺をナイフエッシ にした板を $\mathrm{V}$ 字形の溝で保持して，それぞれ単純支 持の条件を満足させている。 さらに，安井》)は試験片 の周辺にビニールテープをつけ，木枠の溝にはめ込ん で単純支持曲面板の曲げ振動夷験を行っている.しか し本報では，試験片支持部の両面を丸棒で挟むことに より比較的容易に周辺単純支持を実現させることにし た、そのため、大きさが $250 \mathrm{~mm}$ 角で厚さが $20 \mathrm{~mm}$ の 2 枚の鋼板のそれそれの中心部に $130 \mathrm{~mm}$ 角の開口 部を設け, 開口部周辺の試匼片支持部に直径 $12 \mathrm{~mm}$ の磨き丸棒を埋め込んだ試験片取付枠を製作した. 第 3 図はその試験片取付枠の写真であり，振動実験時に は第 4 図のように試験片を取付枠に挟んて、試験片支 持部が回転自由となるようにした。

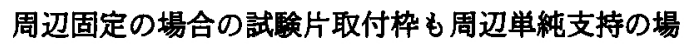
合と同じ寸法の鋼板を使って製作したが，中心部に $150 \mathrm{~mm}$ 角の開口部をもち，試験片接触面を研磨仕上 げした 2 枚の鋼板からなっている．実験の際には，試 験片を取付枠に挟んで16本のボルトに $7.84 \mathrm{Nm}$ (80 $\mathrm{kgf} \cdot \mathrm{m})$ の一定トルクを均等にかけて締め付けた.

\section{3. 線形振助実験}

3.1 実験要領 まず，試臨片を挟んだ取付伜を支 持台上に垂直に設置する．次に，発振器からの正弦波 をパワーアンプで增幅してスピーカに入カし，その音 幚出力をホーン型ノスルで集中させて試験片の中心部 を音翌加振する．そのとき，加振用のスピーカ端子電 压と試験片に接着した压電素子の応答出力電圧とでリ

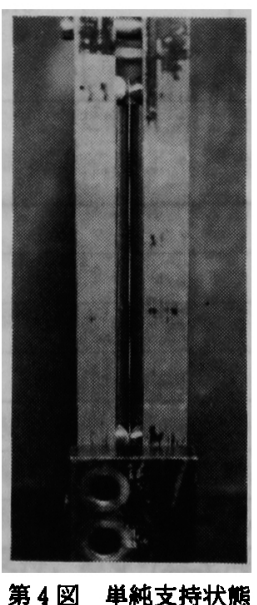


サージュ図形を描かせて固有振動数を測定する 時にレーザホログラフィの時間平均法 ${ }^{10)}$ てそのとき の振動モードを計測する。

ところで，今回製作した二通りの試験片取付枠がそ れそれ全周辺単純支持と全周辺固定の境界条件を満足 していることを確認するために，まず第 1 表に示した 板㫗 $h=1.00 \mathrm{~mm}$ と $h=0.68 \mathrm{~mm}$ の二種類の薄板の線 形振動実験を行った。第 5 図は初期たわみのない板厚 $h=1.00 \mathrm{~mm}$ の薄板 (平板) の振動モードであり，(a) 図の全周辺単純支持板，(b)図の全周辺固定板の両 者とも乱れのない対称なモードが得られており，板厚 $h=0.68 \mathrm{~mm}$ の場合も同様な振動モードが得られた. なお，(a)図の単純支持の場合のモードて，周辺近 傍での干渉じまが切断されているように見えるのは， 第 3 図で示したように鋼板の開口部(130 mm 角)より 単純支持部 $(150 \mathrm{~mm} \times 150 \mathrm{~mm})$ が広く，外面からはそ の支持部が見えないためである．これは，後で示す第 6 図の場合も同様である. 次に同じ薄板（平板）の線 形振動数の值を調ぺてみると，周辺単純支持の場合， 実験值 $f_{\mathrm{ex}}$ は理論值 $f_{\mathrm{th}}$ よりも $3.6 \%$ け高くなって いる。この原因として，試験片と支持用丸棒の間に摩 擦や拘束が生じて，周辺が完全に回転自由とはなり得 なかったことなどが考えられる。これに対して試験片 を二枚の鋼板を挟んで実現させた周辺固定の場合，実 際には弾性固定となるため，逆に実験值 $f_{\mathrm{ex}}$ が理論值 f よりも 3.6\%だけ低くなっている．しかしながら， いずれの場合もその差は小さく，試験片取付枠で挟ま れた試験片はそれそれ全周辺単純支持と全周辺固定の 境界条件をほほ满足しているものといえる。

3.2 補強板の振動モード 第 6 図は全周辺単純支 持板の振動モードの一例て，（a）図は補強材が格子 状に各 10 本配置された二方向補強板，（b)図は補強 材が一方向 (写真ては左右方向) に 10 本配置された一 方向補強板の測定結果である。これら代表例を含めた すぺての測定結果を見ると，全周辺単純支持の場合の 振動モードは，今回製作した試験片では補強材の配置

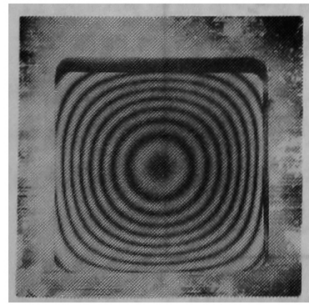

$f_{\text {ox }}=158.9 \mathrm{~Hz}$ $f_{1 n}=153.4 \mathrm{~Hz}$

(a) 全周辺単純支持 第 5 図 初期たかみのない薄板 (平板) の振的モード
方法や本数，あるいは初期たわみの大きさにはほとん ど影響されず，理論解析で仮定した初期たわみのない 場合の薄板のモードとほほ同じものとなった，ただ し，その初期たわみ形状が第 2 図（a）である第 6 図 (b)の一方向補強板の場合のように，最大初期たわ みの位置が板中心からいくぶんずれた非対称な初期た わみ形状をもつ補強板では，その振動モードはやはり 最大振幅点が板中心からずれた非対称な形となった．

これに対して第 7 図の全周辺固定の場合，(a)図 の二方向補強板では初期たわみが大きくなると板中心 付近が平らな振動モードとなる．また（b)図の一方 向補強板では，初期たわみが大きくなるにつれて板中 心近傍の等振幅曲線が円からしだいに補強材に垂直な 方向に細長くなり， $B / h \fallingdotseq 3$ を越えるとついには最大 振幅点が二つに分かれるモードとなるが，その対称性 は保たれている．これは全周辺固定の一方向補強板の 場合，初期たわみが大きくなると，補強材が一方向の みに配置されたことによる異方性の影響が大きく現 れ、このような振動モードとなったものと思われる。 なお，全周辺固定の場合も補強材本数が振動モードに 及ほすす影警はほとんど認められなかった。

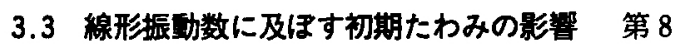
図は，薄板の初期たわみ $B$ による線形角振動数 $\omega$ の

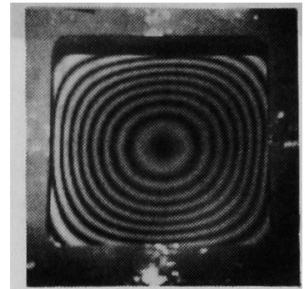

$f_{0 x}=152.5 \mathrm{~Hz}$ $\mathrm{B}=0.55 \mathrm{~mm}$

$(\mathrm{B} / \mathrm{h}=1.52)$

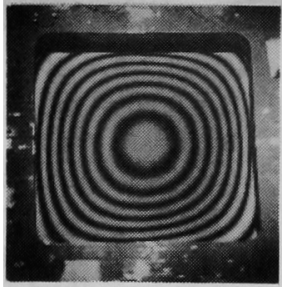

$f_{0 x}=175.8 \mathrm{H} 2$ $\mathrm{B}=0.83 \mathrm{~mm}$

$(B / h=2.20)$

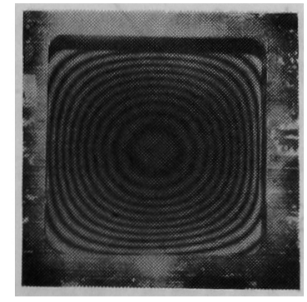

$f_{\text {ox }}=134.7 \mathrm{H} \mathrm{z}$ $B=0.51 \mathrm{~mm}$ $(B / h=1.29)$

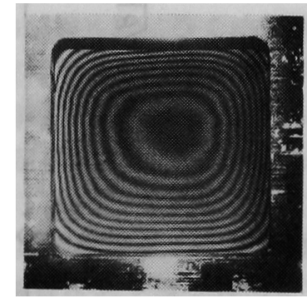

$f_{\text {ox }}=288.6 \mathrm{~Hz}$ $B=2.16 \mathrm{~mm}$ $(\mathrm{B} / \mathrm{h}=5.56)$ (b) 一方向補強板
第6図振動モードに及ほす初期たわみの影留 (全周辺単純支持. $n=10$ 本) 
変化を無次元化して示したもので，破線は面内可動周 辺，実線は面内不動周辺の理諭曲線である。まず， ( a ) 図の周辺単純支持の場合の実験值は面内可動周 辺の理論値によく一致し，(b)図の周辺固定の場合 には，実験值は初期たわみが大きくなるにつれていく

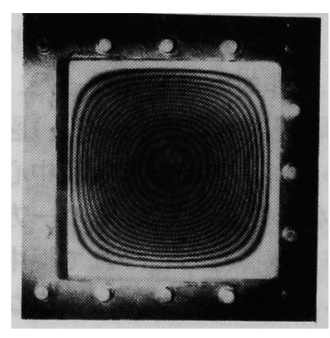

$$
\begin{aligned}
f_{\text {ox }} & =279.0 \mathrm{~Hz} \\
\mathrm{~B} & =0.87 \mathrm{~mm}
\end{aligned}
$$

$(B / h=2.58)$

(a) 二方向補强板

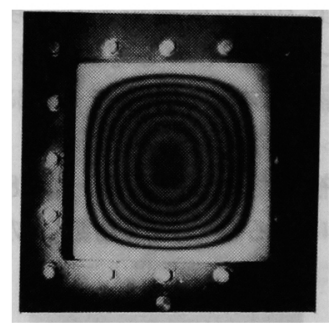

$$
f_{\text {ox }}=229.3 \mathrm{~Hz}
$$

$\mathrm{B}=0.66 \mathrm{~mm}$

$(\mathrm{B} / \mathrm{h}=1.74)$

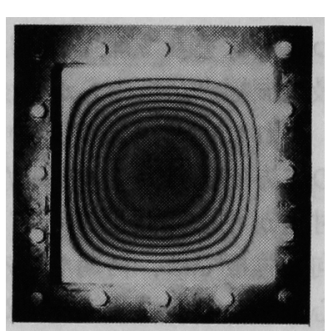

$f_{\text {ox }}=347.9 \mathrm{~Hz}$ $B=1.39 \mathrm{~mm}$

$(B / h=4.10)$

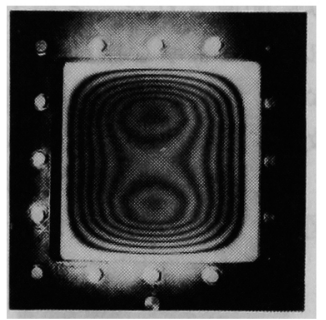

$f_{\text {ox }}=325.7 \mathrm{~Hz}$

$B=1.44 \mathrm{~mm}$

$(B / h=3.92)$

強 板

第 7 図振動モードに及はす初期たわみの影翠 (全周辺固定， $n=10$ 本)

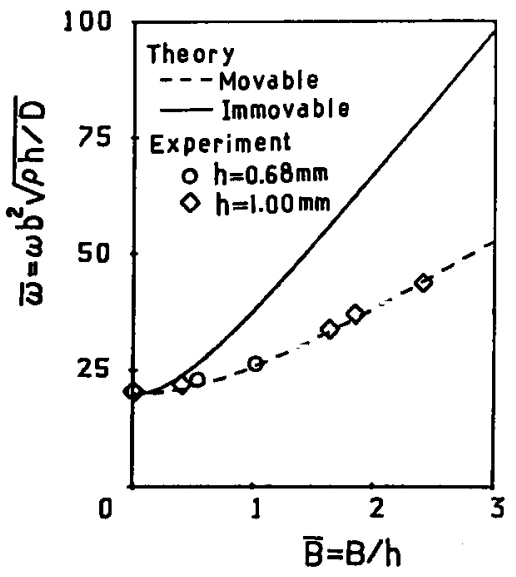

（a）全周辺単純支持
ぶん面内可動周辺の理論曲線に沿う形で高くなってい る.しかも両者とも，実験值のばらつきは非常に少な (.

第 9 図から第 12 図までは補強板の場合で, 初期た わみによる線形振動数の変化を, 縦軸に非補強板の振 動数パラメータで無次元化した振動数 $\bar{\omega}=$ $\omega b^{2} \sqrt{\rho h / D}$, 横軸に最大初期たわみ $B$ を非補強板厚 さ $h$ で割った無次元初期たわみ $\bar{B}=B / h$ をとって示 したものである.ただし， $D$ とのは補強材がないと 考えたときの非補強板の曲げ剛性と密度である．また 各試験片で剛性比の值は多少異なるが，理論曲線は代 表値として第 2 表の値を用いて計算したものである. なお，ねじり剛性比 $\beta_{\mathrm{sr}}$ は第 2 表の各寸法を( 2 )式と （1）式に代入すると補強材本数 $n$ によって多少異な つた值となるが，平均的な值を採って二方向補強板て は $\beta_{\mathrm{sr}} \fallingdotseq \beta_{\mathrm{s}}+\beta_{\mathrm{r}}=18$, 一方向補強板ては $\beta_{\mathrm{sr}} \fallingdotseq \beta_{\mathrm{s}}=10$ として計算した。.ところて，これら補強板の場合の実 験值は、第 8 図の薄板の場合に比べていくぶんばらつ きが見られる。これは各補強板試験片で剛性比の值が 多少異なるためであるが, 補強材本数が線形振動数に 及涩す影響は振動モードの場合と同様にほとんど認め られない。

次に第 9 図と第 10 図の全周辺単純支持の場合, 線 形振動数の実験值は二方向補強板，一方向補強板とも に面内可動周辺の理論曲線に近い值となるが，第 8 図 （a）の薄板の場合に比へて面内可動の理論値よりは いくふん高い値となる．これは，第1図でしたよう に試験片周辺がエッチングされず補強材と一体となっ ているため，周辺を丸棒で挟んだ試験片の曲げ喵性と

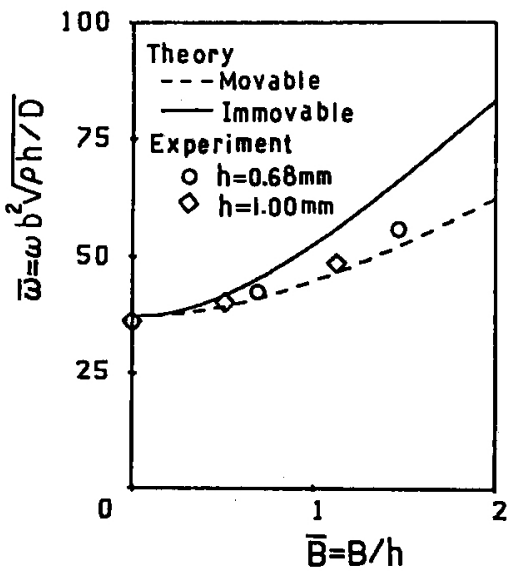

（b）全周辺固定

第 8 図薄板の線形角振助数 $\omega$ と初期たわみ $B$ の関係 


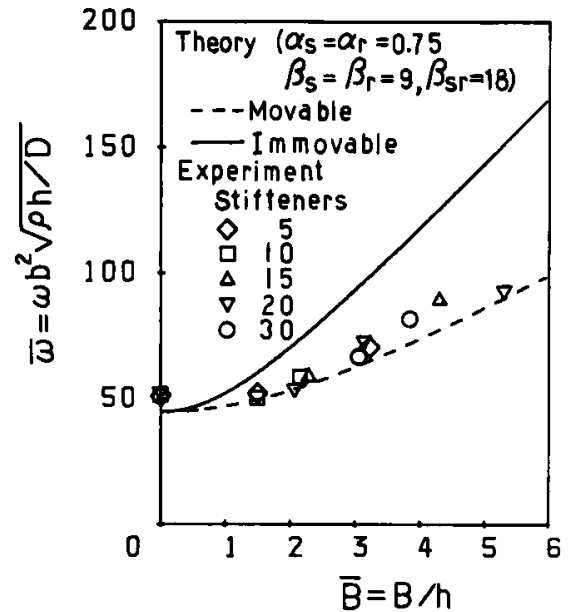

第 9 図 線形角振動数 $\omega$ と初期たわみ $B$ の関係 (全周辺単純支持，二方向補強板）

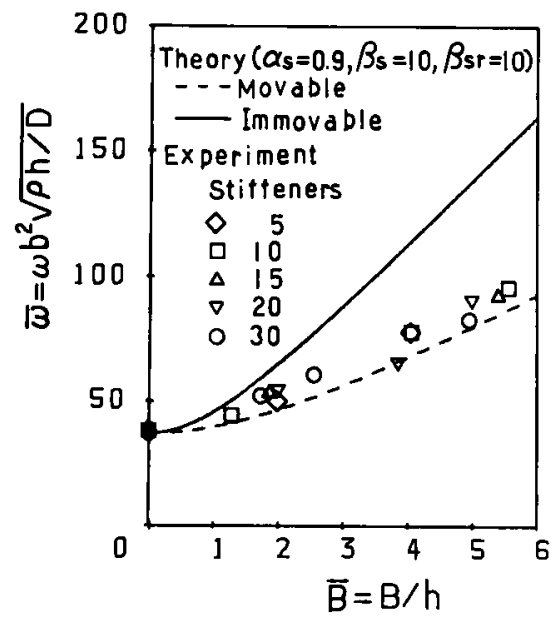

第 10 図線形角振峌数 $\omega$ と初期たわみ $B$ の閔保 (全周辺単純支持，一方向㭪強板)

ねじり哃性が計算值よりも大きくなり，実験で求めた 振動数が高くなったものと考えられる．また第 11 図 と第 12 図の周辺固定の場合には，初期たわみが大き くなると振動モードが理論解析で仮定した余弦曲面と は異なる傾向にあるものの，線形振動数の実験值はこ の場合も二方向補強板，一方向補強板ともに面内可動 周辺の理論曲線に近い值となっている．しかも実験值 は, 二つの理論曲線に対して第 8 図(b)の薄板の場 合とよく似た傾向にある。したがって， smeared out 法は今回㱔作した試酫片形状に類似した補強板に対し ては補強材本数に無関係に適用でき，初期たわみを有 する補強板の曲げ振動解析では有効な手法となること がかかる。

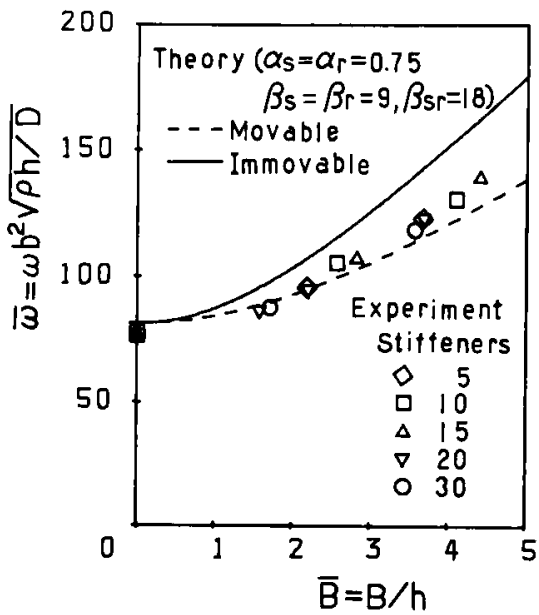

第 11 図 線形角振動数 $\omega$ と初期たわみ $B$ の関係 (全周辺固定, 二方向補強板)

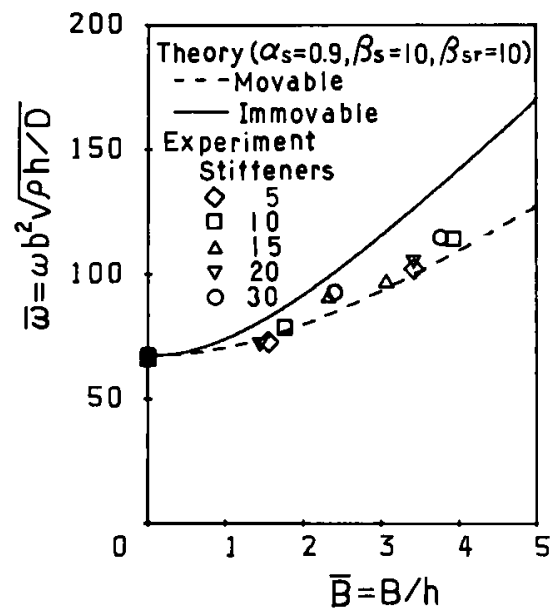

第 12 図 線形角振㨁数 $\omega$ と初期たわみ $B$ の関保 (全周辺固定，一方向補強板）

\section{4. 非線形振動実験}

今回整作した周辺単純支持の試験片取付枠では，振 動変位が大きくなると試験片支持部を回転自由でかつ 変位拘束の状態にすることが困難であった．したがっ て、非線形振動実験は周辺固定板に対してのみ行っ た.

4.1 実験要領 第 13 図に周辺固定板の非線形振 動実験装置の概略を示す，実験は次の手順で行った。 まず試験片(1)を挟んた取付枠(2)を，4個の支持台(3)上 に水平に設置してクランプ(4)で固定する．次に，線形 振動実験と同様にスピーカ(5)による音響加振を行い， 試験片中央点の振動変位を湘定範囲 $\pm 1 \mathrm{~mm}$ の非接触 型変位形6で測定する，ところて，初期たわみを有す 

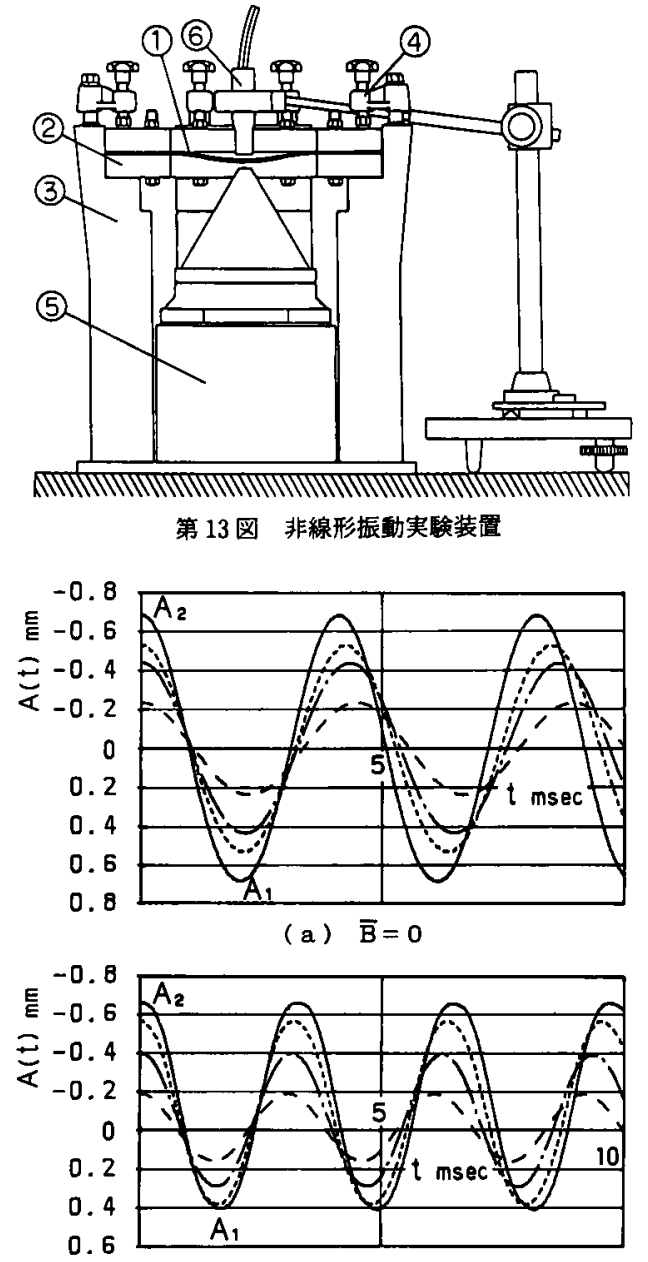

(b) $\bar{B}=3.70 \quad(B=1.30 \mathrm{~mm})$

第 14 図板中心点の振動変位 (二方向補強板， $n=5$ 本)

る板の非線形振動は，振幅の増加につれて固有振動数 が高くなる hardening type と低下する soft-spring typeの二通りがある．実験では，音響出力を一定に 保ち，加振振動数を変化させて共振点を求めたが，そ の際，振幅が最大振幅点に到達せずにジャンプするこ とを避けるため, hardening type の試験片に対して は加振振動数を増加させていった場合に, soft-spring typeの試験片では減少させていった場合に，それぞ れ振動変位がシンクロスコープ上で極大を示すときの 振動数を固有振動数とした 変位はデジタルメモリに読み込ませてパーソナルコン ピュータで処理して計測した。

4.2 振功变位 初期たわみを有する補強板の大振 幅振動問題では，初期たわみのたわみ線から曲率の增

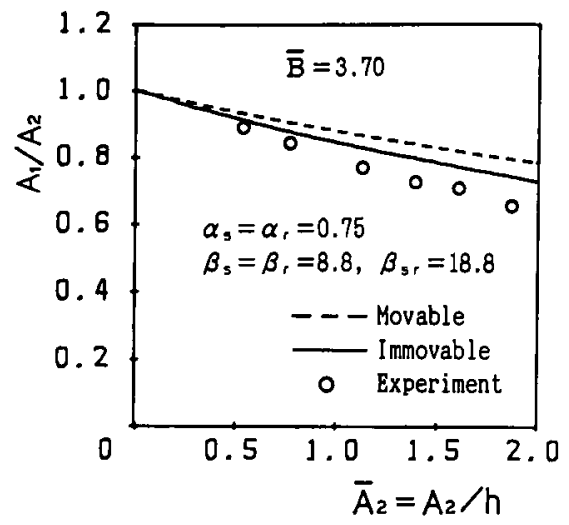

第 15 図 振幅比 $A_{1} / A_{2}$ と振幅 $A_{2}$ の関係 (二方向補強板, $\bar{B}=3.70, n=5$ 本)

加する方向への振幅 $A_{1}$ と曲率の減少する方向への振 幅 $A_{2}$ ではその大きさが異なり，それらの間には第 2 報の (27)式の関係が成立する．第 14 図は板中央点の 振動変位の測定結果の一例であり，(a)図の初期た わみのない補強板は振幅の大きさが等しい $A_{1}=A_{2}$ の 振動を行っているのに対し，(b)図の初期たわみを 有する補強板は初期たわみのたわみ線近傍て安定な周 期振動を行い，しかも曲率の減少方向への振幅 $A_{2}$ が 曲率の増加方向への振幅 $A_{1}$ よりも常に大きくなって いる.このことをより明確にするために，振幅 $\overline{A_{2}}=$ $A_{2} / h$ に対する $A_{1} / A_{2}$ の関係を示したものが第 15 図 て，図中の○印は実験の振動波形から読み取った值， 破線と実線は第 2 報の(27)式で計算した面内可動周辺 と面内不動周辺の理論曲線である．この図によれば， 常に $A_{1} / A_{2} \leqq 1$ の関係が成立し，しかも振幅 $A_{2}$ の增 加につれて $A_{2}$ と $A_{1}$ の差が増大していくことがわか る.

4.3 固有振耍数の振幅依存性 第 16 図と第 17 図 は固有振動数の振幅依存性をより明瞭に示すため，縦 軸に非線形角振動数 $\omega^{*}$ を線形角振動数 $\omega$ で割った振 動数比 $\omega^{*} / \omega$ を，横軸に曲率の減少方向への振幅 $A_{2}$ を非補強板厚さ $h$ で割った無次元振幅 $\bar{A}_{2}=A_{2} / h$ を とって図示したものである.これらの図で，○印は実 験結果, 破線と実線は

$$
\omega^{*} / \omega=1 /\left(T^{*} / T\right)
$$

の比周期 $T^{*} / T$ の項に第 2 報の(28)式を代入して計 算した面内可動周辺と面内不動周辺の理論曲線であ る、また，図中に線形角振動数 $\omega$ の值を示した.

まず，第 16 図は初期たわみのない $(\bar{B}=0)$ 補強平 板の場合てあるが、いわゆる hardening type となり。 しかも振動数比 $\omega^{*} / \omega$ の実験值は面内不動周辺の理論 曲線によく一致している．次に，第 17 図(a)のよう に初期たわみ $\bar{B}$ が振幅 $\overline{A_{2}}$ の最大值 2 よりも小さな 


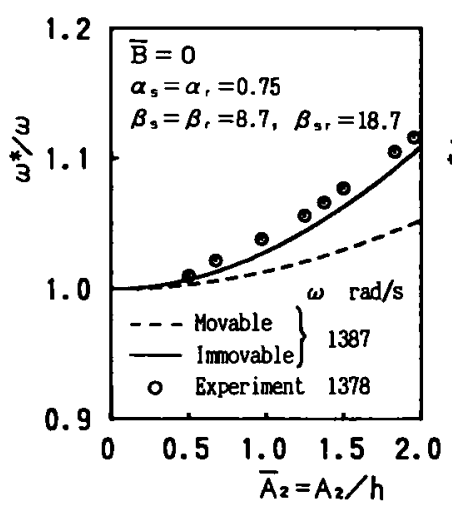

(a) 二方向補強板 $(\mathrm{n}=5$ 本)

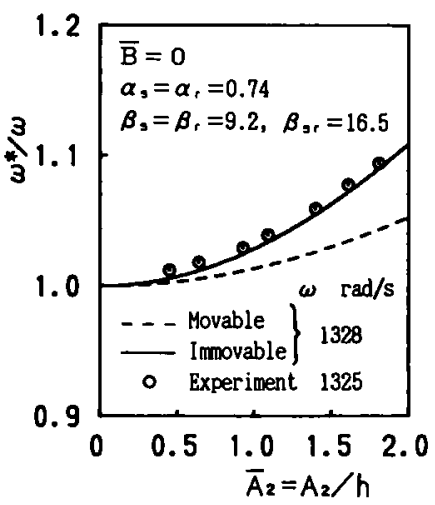

(b) 二方向補強板 $(\mathrm{n}=20$ 本)

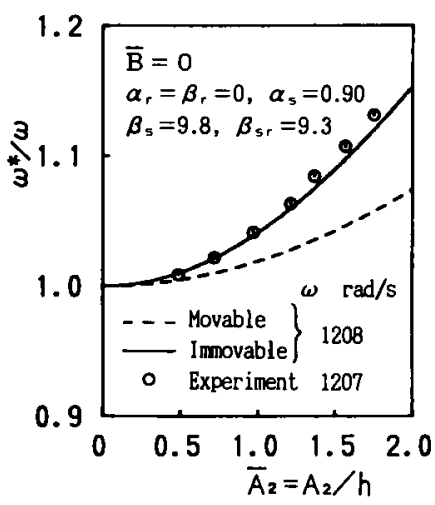

(c) 一方向補強板 $(\mathrm{n}=20$ 本)

第 16 図 振動数比 $\omega^{*} / \omega$ と振幅 $A_{2}$ の関係 $(\bar{B}=0)$

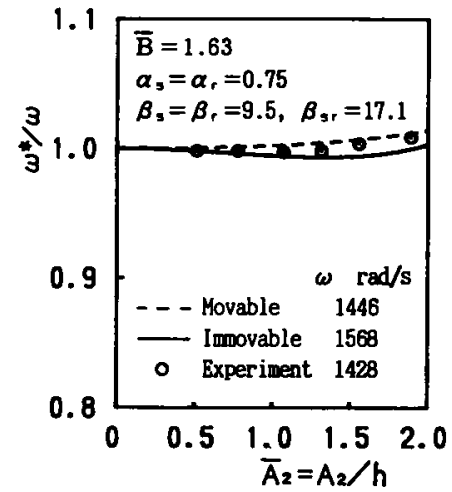

(a ) $\bar{B}=1.63$ の二方向補強板 $(n=20$ 本)

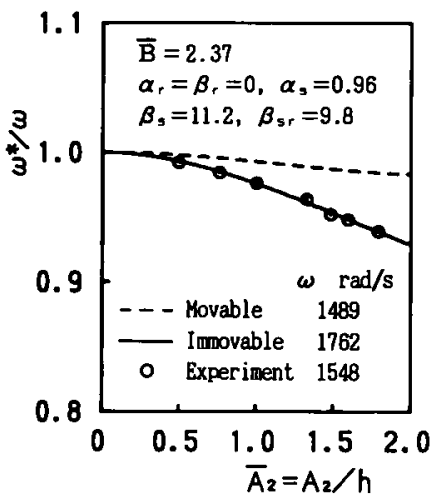

(b) $\bar{B}=2.37$ の方向補強板 $(\mathrm{n}=30$ 本)

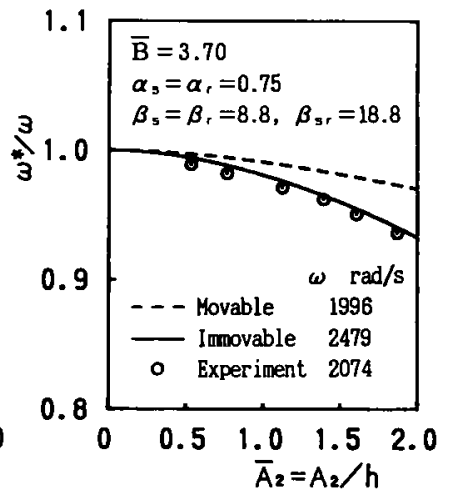

(c) $\bar{B}=3.70$ 二方向補強板 $(\mathrm{n}=5$ 本)

第 17 図振動数比 $\omega^{*} / \omega$ と振幅 $A_{2}$ の関係

場合には，振幅 $\overline{A_{2}}$ が初期たわみ $\bar{B}$ の大きさに等し い1.63 付近を越えるまで非線形角振動数 $\omega^{*}$ の值は ほとんど変化せず，振幅がそれ以上の大きさになると 振動数はわずかに増加し始める。これに対して，第 17 図(b)，(c)からわかるように初期たかみ $\bar{B}$ が振 幅 $\bar{A}_{2}$ の最大値 2 よりも大きな補強板の場合は，初期 たわみのない場合とは異なり soft-spring type とな る. しかも，振動数比 $\omega^{*} / \omega の$ 実験值はいずれの場合 も面内不動周辺の理論值によく一致しており，理論解 析で用いた逐次近似法は初期たわみを有する補強長方 形板の非線形振動問題にも十分適用可能であるといえ る.

\section{5. 結}

本報は，初期たわみを有する補強長方形板の基本振 動について，線形および非線形の振動実験を行ってそ の振動特性を調べ，さらに前報 ${ }^{1,2\rangle}$ の解析結果と比較
して理論の妥当性を検討したものである，得られた結 果を要約すると次のと扔りである。

（1） smeared out 法は，初期たわみを有する補強 長方形板の曲げ振動問題に対して有効な手法である.

（2）逐次近似法で求めた振動数比 $\omega^{*} / \omega$ の值は実 験值とよく一致し，初期たわみを有する補強長方形板 の非線形振動問題にも十分適用可能である.

（3）初期たわみを有する補強長方形板の固有振動 数は，初期たわみが小さい場合には振幅の増加ととも に高くなるが、初期たわみが大きくなると逆に振幅の 增加につれて低下する。

最後に，実験装置の製作や基礎実験を修士論文や卒 業論文として行われた児玉 克氏，中村竜三氏（とも に現在 三菱重工業株式会社)，林 裕二氏(現在 $\checkmark$ ツダ株式会社）に感謝の意を表します。 


\section{参考文献}

1）角誠之助, 有富正男, 桐岡 健: 初期たわみを有する補強長 方形板の非線形自由振動 (第 1 報)周辺単純支持板の理論 解析，日本航空宇宙学会誌，36 (1988)，pp. 418-426.

2）角諴之助, 有富正男, 竹内健典：初期たわみを有する補強長 方形板の非線形自由振動 (第 2 報) 周辺固定板の理論解析, 日本航空宇宙学会誌, 38 (1990)，pp. 405-413.

3) Hoppmann, W. H., II, Huffington, N. J. and Magness, L. S. : A Study of Orthogonally Stiffened Plates, Trans. ASME, J. Appl. Mech., 23 (1956), pp. 343-350.

4) Hoppmann, W. H., II and Magness, L. S. . Nodal Patterns of the Free Flexural Vibrations of Stiffened Plates, Trans. ASME, J. Appl. Mech., 24 (1957), pp. 526530.

5) Olson, M. D. and Hazell, C. R.: Vibration Studies on Some Integral Rib-Stiffened Plates, J. Sound Vib., 50 (1977), pp. 43-61.

6）斎藤秀雄, 山口秀谷：粘弾性ばりを有する長方形弾性平板 の振動，日本機械学会論文集 (C 編)，46（1980），pp. 237244.

7) 安井 淳: 薄肉の長方形曲板の振動特性の研究，日本機械 学会論文集, 38 (1972), pp. 3119-3128.

8) Phillips, I. G. and Jubb, J. E. M.: The Effect of Distortion on the Lowest Natural Frequency of a Rectangular Steel Plate, J. Sound Vib.. 33 (1974), pp. 41-48.

9) 西村源六郎：振動工学，䧕文堂新光社，東京，1969，pp. 1620.

10）角誠之助: 棈造強度解析におけるレーザの応用, 日本航空 宇宙学会誌, 25 (1977), pp. 259-268.

11) 戸田盛和, 渡辺傎介: 非線形力学, 共立出版, 東京, 1984, pp. 80-82.

12）大富浩一：多数の補强はりを有する長方形板の振動ならび に座届問題，日本機械学会論文集 (C 編)，50 (1984)，pp. 1381-1389.

13）川上益男: 局部振動について。造船協会誌，410（1963）, pp. 391-403.

14）粕戸口英善：弾性学, 共立出版, 東京, 1975，pp. 65-73.

\section{付録 補強材のねじり剛性について}

本文中の第 1 図の直交補強板を smeared out 法に より等価な直交異方性板に置き換える際，補強材のね じ剛性をとのように算定するかが問題となる．例え ば, 大富 ${ }^{(2)}$ は補強材 1 本の図心まわりのねじり剛性
を単純に加え合わせた。

$$
G J_{\mathrm{s}}=2 G \frac{h_{\mathrm{s}}{ }^{3} w_{\mathrm{s}}}{3} \cdot f\left(\frac{w_{\mathrm{s}}}{h_{\mathrm{s}}}\right)
$$

を用い。また川上 は流面補強板の補強材ねじり剛 性をねじりの中心が補強板の中立面であることを考虑 して求めており。これを両面対称補強板に適用すると

$$
G J_{\mathrm{s}}=2 G\left[\frac{h_{\mathrm{s}}^{3} w_{\mathrm{s}}}{3} \cdot f\left(\frac{w_{\mathrm{s}}}{h_{\mathrm{s}}}\right)+\left(\frac{h+h_{\mathrm{s}}}{2}\right)^{2} h_{\mathrm{s}} w_{\mathrm{s}}\right]
$$

が考えられる。しかしながら，本報では補強材がイン ティグラルスチフナーであることを考虑して

$$
\begin{aligned}
G J_{\mathrm{s}}= & G\left[\frac{\left(h+2 h_{\mathrm{s}}\right)^{3} w_{\mathrm{s}}}{3} \cdot f\left(\frac{w_{\mathrm{s}}}{h+2 h_{\mathrm{s}}}\right)\right. \\
& \left.-\frac{h^{3} w_{\mathrm{s}}}{3} \cdot f\left(\frac{w_{\mathrm{s}}}{h}\right)\right]
\end{aligned}
$$

なるねじり剛性を考えた。ただし、これらの式中の関 数 $f\left(\lambda_{\mathrm{s}}\right)$ は

$$
\begin{array}{r}
f\left(\lambda_{s}\right)=1-\frac{192}{\pi^{5}} \cdot \frac{1}{\lambda_{s}} \Sigma \frac{1}{m^{5}} \tanh \frac{m \pi \lambda_{s}}{2} \\
(m=1,3,5 \cdots)
\end{array}
$$

で与えられるが ${ }^{14)}$ ，本文の第 2 表に示す寸法をもつ補 強板試験片では，各式中の変数の值が

$$
\left.\begin{array}{l}
w_{\mathrm{s}} / h_{\mathrm{s}} \geqq 7.2, \quad w_{\mathrm{s}} / h \geqq 6.6 \\
w_{\mathrm{s}} /\left(h+2 h_{\mathrm{s}}\right) \geqq 2.3
\end{array}\right\}
$$

となるので，本報では関数 $f\left(\lambda_{s}\right)$ を

$$
f\left(\lambda_{\mathrm{s}}\right) \fallingdotseq 1-\frac{192}{\pi^{5}} \cdot \frac{1}{\lambda_{\mathrm{s}}}
$$

で近似することにした．そこでいま，初期たわみのな

\begin{tabular}{|c|c|c|c|c|c|c|}
\hline & & 実験值 & \multicolumn{2}{|c|}{ (A-2)式を用いた理論值 } & \multicolumn{2}{|c|}{ (A•3)式を用いた理論值 } \\
\hline & & $f_{\text {ex }} \mathrm{Hz}$ & $\beta_{\mathbf{s r}}$ & $f_{\mathrm{th}} \mathrm{Hz}$ & $\beta_{\text {sr }}$ & $f_{\text {th }} \mathrm{Hz}$ \\
\hline 単 & 二方向補強板 & 133.2 & $7 . n$ & 95.8 & 18.6 & 115.7 \\
\hline 支 & 一方向補強板 & 109.7 & 3.4 & 87.6 & 10.0 & 106.0 \\
\hline 固 & 二方向補強板 & 207.5 & 6.2 & 193.3 & 16.5 & 211.3 \\
\hline 定 & 一方向補強板 & 192.1 & 3.2 & 175.7 & 9.3 & 192.3 \\
\hline
\end{tabular}
い $n=20$ 本の補強板試験片を例にとって，上式の $f\left(\lambda_{\mathrm{s}}\right)$ を $(\mathrm{A} \cdot 2)$ 式と $(\mathrm{A} \cdot 3)$ 式に代入してねじり剛性を 計算し，さらにその值を用いた線形振動数の理論值を 実験結果と比較したものが付表 1 てある。この結果か ら，(A·3)式で計算するほうが実験值に近く，適切で あるものと思われる。したがって，本報てはねじり抵 抗 $J_{\mathrm{s}}$ は本文の $(2)$ 式で計算することにした。

付表 1 初期たわみのない補強板の線形振䑤数 $(n=20$ 本) 